Journal of

\title{
Education and Practice
}

(JEP)

Phone Cameras and the Internet as it affects the Photographic Abilities of Students in South-South Nigeria

Dr. Frank .I Uti
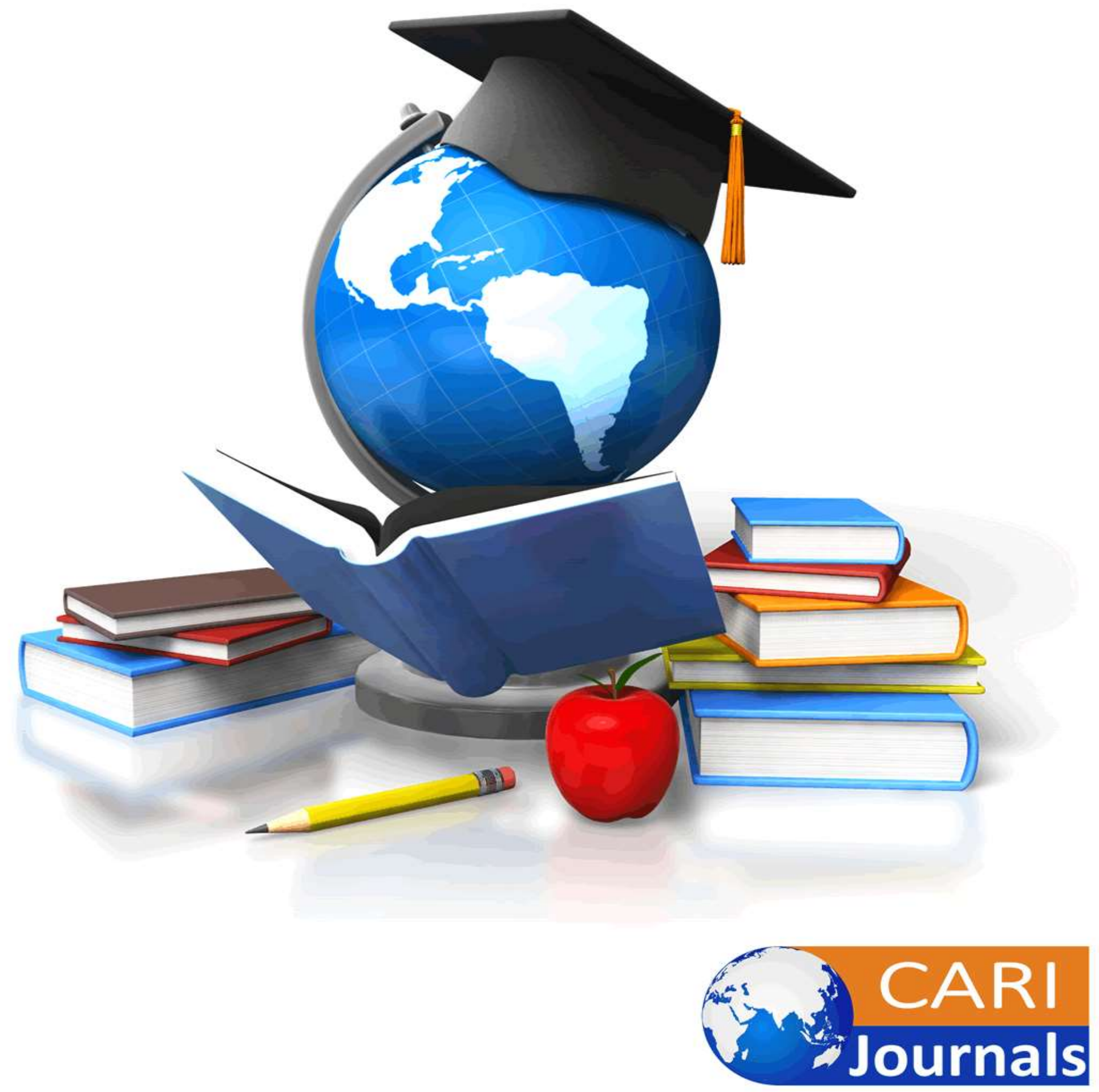
Journal of Education and Practice

ISSN 2520-467X (Online)

Vol.5, Issue No.4, pp 23 - 30, 2021

www.carijournals.org

\title{
Phone Cameras and the Internet as it affects the Photographic Abilities of Students in South-South Nigeria
}

\author{
Dr. Frank .I Uti \\ NCE, BA (ED. Graphics), MA (Art Ed. Graphics), Ph,D (Art Ed.) \\ Lecturer, \\ Department of Visual Arts and Technology \\ Faculty of Environmental Sciences \\ Cross River University of Technology (CRUTECH) \\ Calabar, Cross River State
}

Nigeria.

\begin{abstract}
Illustrations when captured using cameras help its mastery, but photographic skills have been hampered by the discovery of the digitalised camera phone manufactured by Samsung and released in South Korea in June of 2000. Photographic skills have further been slowed down by the coming of the internet. To cover this empirical study, one objective and research question was used. The study therefore examined the effects of phone cameras and the internet on the photographic abilities of students in South-South Nigeria. The target population was students who studied Fine and Applied Arts that specialized in graphics. The population only involved the years three and four students. The methodology was a quantitative survey which applied the interview of students and lecturers. The cluster and purposive sampling method was applied. Data was analyzed using simple percentages. Fifty two students in all were interviewed and presenting four questions while those of lectures was eleven presenting two questions. The action of students in this study was greatly influenced by two theories. The theory of social exchange which is maximized by rewards and minimized by costs and the theory of reinforcement, the stimuli coming from the teachers being quiet on the students direction. The results indicated that the student's photographic knowledge was negatively affected by the use of phone cameras and the use of the internet especially on their phones. This situation was accentuated by their teachers not insisting on how or where to obtain illustrations. The recommendations included their lecturers insisting on the use of professional cameras, the university authorities providing quality professional cameras for study purposes and lecturers must insist that students avoid the use of phone camera for their illustrative assignments because its provides another avenue to download and copy.
\end{abstract}

Key words - Fine and applied arts, phone cameras, illustrations, photographic skills and use of the internet. 
Journal of Education and Practice

ISSN 2520-467X (Online)

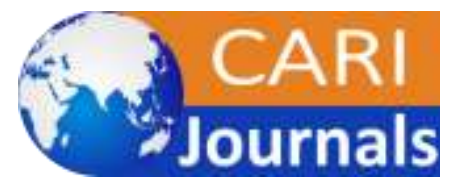

Vol.5, Issue No.4, pp $23-30,2021$

Www.carijournals.org

\section{Introduction}

For every skill that must be acquired time must be spent to gain knowledge of it. This was supported by Valerio (2018) when he wrote that "it takes a lot of practice to become good at something, while the skill part takes hundreds, if not thousands of hours" to obtain. This is true of photographic skills, which students in art schools are taught, especially those specializing in the graphic arts. Josh (2018) writes that the first things one should know concerning the camera before venturing into photography is the aperture and shutter speed. The aperture controls the entry of light while the shutter speed has different speed levels. He says that these are elements that the intending photographer needs to know before creating an exposure and that knowing this part helps them take control of the camera. But a problem has been created by the emergence of different technologies, as the internet and the camera phone which are meant to make life easier.

Art students of universities and other tertiary schools no longer see the professional camera as the equipment to use for class work but rather depend on their camera phones. This has been made easier by the high cost of obtaining professional cameras. More so their phones been handy with the internet, on provocation of any assignment having to do with illustrations from their lecturers they go sourcing for one, especially when their lecturers do not insist on where or how to source for illustrations. These factors have helped to affect negatively the creative photographic abilities of graphic art students in universities.

Illustration is an essential part of designing graphic layouts. How it is sourced for is also very important. Illustrations could be generated using photographic methods or by drawings from real life actions. Illustrations are displayed visualization, which could come as drawings, paintings, photographs or other works of art that are presented to indicate sensual information by providing visual representation graphically. Zhihui (1996) opines that, Illustrations serve to expand, explain, interpret or decorate an idea. He writes that they perform certain functions that may differ from those of gallery paintings. According to Collins (2015), an illustration is a drawing, painting or painted work thatxplains, clarifies, illuminates, visually represents or merely decorates a written text, which may be of a literary or commercial nature. Newspapers were the earliest area where illustrations were used. Collins (2015) further asserts that historically, book illustrations, magazines, newspaper illustrations have been the predominant forms of this type of visual arts. Illustrators have also used their graphic skills in the fields of poster art advertisements, comic books and animation art. It would be necessary to originate one if needed instead of having to lift, alter and use photographs or drawings created by another that is already published for graphic purposes. In the process of originating one through their camera, a greater understanding of its parts increases and brings about originality.

\section{Theoretical Framework}

This study is been linked to two psychological theories; which are social exchange theory that lies between sociology and psychology and the theory of reinforcement. The social exchange theory has its concept based on costs and rewards that drive human decisions and behavior. Lomg-Crowell and Levitas (2021) in their instructions to students stated that social exchange theory as propounded by George Homans in 1958 tries to maximise rewards and minimise costs in relationships. In other words, costs and rewards influence people's decision. Though the 
Journal of Education and Practice

ISSN 2520-467X (Online)

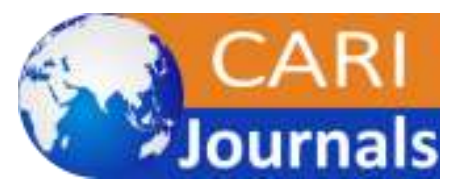

Vol.5, Issue No.4, pp $23-30,2021$

www.carijournals.org

theory studies relationships between two or more parties, the parties may depend on how one conceptualises the theory.

In this study, the concept is based on the person, phone and camera; though the phone and camera are inanimate. The three parties have a relationship; that relationship depends on the person having a mobile phone that has a digital camera. At certain points they become inseparable, such that when the thought of a professional camera as a single entity is broached its cost makes the person shrink and the thought would be of the cost. So why spend that much money when there is a camera in my phone?

In this study, The theory of social exchange potents in this study that the student who has a mobile phone would never think of getting a professional camera to do his work, when he has a camera in his phone. This affects the students ability to handle a professional camera and in some ways his professional competence negatively, without recognizing it. The rewards he gets from the phone camera and the professional camera is about the same, he therefore does not care whichever he uses. This virtually becomes his habit in executing any illustrative work. This mode of behavior now reinforced by their teachers not insisting on what their students use in the process of their work. This ties the study to the theory of reinforcement.

The theory of reinforcement as proposed by B. F. Skinner in his operant conditioning is according to Culatta (2021) based on learning as a function of change, that the changes in behavior are the result of stimuli. When a particular response pattern is reinforced (rewarded) the individual is conditioned to respond. He emphasizes that reinforcement is the key element of Skinners theory. A reinforcer is anyone that strengthens the desired response. When related to this study the reinforcers of the use of phone camera by students for illustration are the teachers. The teachers do not insist on the use of professional camera's possibly for its unavailability or its cost, beyond the reach of students or by simple non-challancy. This position of the teachers has encouraged students to continue using phone cameras for assignments that has to do with illustration. In the words of Culatta ibid the reinforcer provides verbal praise, a good grade or a feeling of accomplishment or satisfaction. Since their use of phone cameras are encouraged; the students sees nothing wrong and it therefore becomes a quick response to his creativity calls.

Umegbewe, Ateh-Abang and Agbor (2010) in their journal article wrote about reinforcement is the process of increasing or stamping a desirable behavior. Though, the word "desirable" is used, the desirability affects the student's use of professional cameras negatively. This therefore behooves their teachers and art institutions to find ways to positively influence creativity by getting the right tools for learning, in this case the professional cameras.

\section{Statement of the Problem}

Hill (2013) noted that camera phones first came into existence in 2000. Since it came into existence he wrote that few saw the need for dedicated devices for taking photos and videos. This situation has affected not only the graphic artist but artist generally who are meant to be professionals in the use of cameras. Phone cameras have becomes a common equipment for sourcing for illustrations. The phones too also bearing internet devices have made easy the source for information which also includes illustrations. These two factors have led the 
Journal of Education and Practice

ISSN 2520-467X (Online)

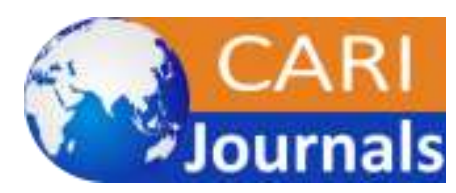

Vol.5, Issue No.4, pp $23-30,2021$

www.carijournals.org

undergraduate graphic artist not fully acquiring the necessary photographic abilities they need for their profession.

\section{Objective of the Study}

Only one objective was adopted, for the purpose of this study which states; to ascertain if dependence on illustrations generated from the internet affected the creative photographic abilities of graphic art students in South-South of Nigerian universities.

\section{Research Question}

Does the illustration generated from the internet affect the creative photographic abilities of students in graphics in Nigerian Universities especially in the South-South?

\section{Methods}

The area of study for this research was the South-South region of Nigeria. From this area, Federal and State owned universities were chosen because most of them have the Department of Fine and Applied Arts amongst their academic programs. The universities chosen were University of Uyo, Uyo, Akwa Ibom State, University of Benin, Benin City, Edo State, University of Port Harcourt, Port Harcourt, River State, Ignatius Ajuru University of Education, Port Harcourt, River State, Niger Delta University, Amassoma, Bayelsa State, Delta State University, Abraka, Delta State and Cross River University of Technology, (CRUTECH), Calabar. The research design used was the quantitative survey technic. This was employed to find out to what extent the photographic abilities of graphic art students have been affected in Nigerian Universities.

The population of this research work was made-up of all graphic art students of Federal and State Universities within the South-South States of Nigeria that have Fine and Applied arts Departments up to three and four hundred levels. The interview method was used to find first out their use of cameras. The sample population of interviewed students was 52 this makes up the number of students on ground while sample population of lecturers interviewed was 11 . The Federal and State Universities were chosen because the governments have been consistent in developing the Fine and Applied Arts Department of the various universities. The cluster sampling technique was used. The technique required that students of each level found on sight were taken. The year three and four students were chosen because, at this point students were expected to specialize in either the Fine Arts or the Applied Arts. The Fine arts has two areas which are painting and sculpture, while the applied arts include graphics, textiles and ceramics. The sampling technique was also purposive, because only the graphic art students belonged to the population. The graphic students engage more with assignments that requires photographic and illustrative capabilities. The data was analysed using simple percentage The results were presented in tables using figures (See table one, two and three). 
Journal of Education and Practice

ISSN 2520-467X (Online)

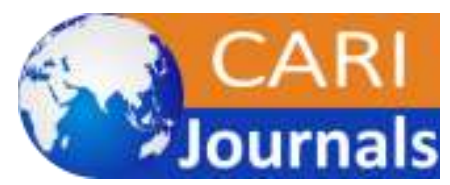

Vol.5, Issue No.4, pp $23-30,2021$

www.carijournals.org

\section{Results}

The only research question asked; if the dependence on illustrations generated from the internet affected the creative ability of students in graphics in Nigerian Universities especially in the South-South. The following tables represents questions asked and results in percentages.

Table One: Representing data on first choice of source of illustrations

\begin{tabular}{|l|l|c|c|c|}
\hline Items & Item description & Internet & Personal photos & Sample size/\% \\
\hline & $\begin{array}{l}\text { What is your first place } \\
\text { choice for source of } \\
\text { illustrations? }\end{array}$ & $(38)$ & $(14)$ & 52 \\
\hline & $\begin{array}{l}\text { Do your lecturers insist on } \\
\text { where you get illustrations? }\end{array}$ & $(19)$ & $(33)$ & $100 \%$ \\
\hline
\end{tabular}

\section{Interview on source of Illustrations}

When it was asked what their first place choice for sourcing for illustration was? 38 of them making up $\mathbf{7 3 \%}$ said that internet; while 14 representing $27 \%$ said personal photographs. They were asked if their lecturers insisted on where they get their illustration? 19 of them representing $\mathbf{3 7 \%}$ said yes; while 33 of them representing $\mathbf{6 3 \%}$ of them said no. (Table one)

Table Two: Representing data from the knowledge of Camera

\begin{tabular}{|l|l|c|c|c|}
\hline Items & Item description & Internet & Personal photos & Sample size/\% \\
\hline & $\begin{array}{l}\text { What is the purpose of the } \\
\text { aperture in a camera }\end{array}$ & $(45)$ & 52 \\
\hline & $\begin{array}{l}\text { Have you ever thought of } \\
\text { the reason you study } \\
\text { photography? }\end{array}$ & $(33)$ & $(19)$ & $100 \%$ \\
\hline & $63 \%$ & $37 \%$ & $100 \%$ \\
\hline
\end{tabular}

Interview on knowledge of camera 
Journal of Education and Practice

ISSN 2520-467X (Online)

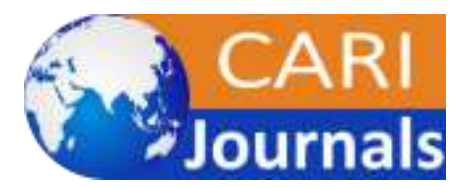

Vol.5, Issue No.4, pp $23-30,2021$

$\underline{\text { www.carijournals.org }}$

They were asked the purpose of the aperture in a camera? 45 of them representing $87 \%$ said they do not know while 7 representing $13 \%$ said they knew and they were also asked if they ever thought of the reason they study photography? 33 of them making up $63 \%$ said No; that they have never really thought about it, while 19 making up $\mathbf{3 7 \%}$ said yes; that sometimes they think of it, but never really to a conclusion. (See table two).

Table Three: Representing interview of lecturers

\begin{tabular}{|l|l|c|c|c|}
\hline Items & Item description & Internet & Personal photos & Sample size/\% \\
\hline & $\begin{array}{l}\text { Do you insist on students } \\
\text { using photographic methods } \\
\text { to source for their } \\
\text { illustrations? }\end{array}$ & $73 \%$ & 11 \\
\hline $\begin{array}{l}\text { Have you ever thought of } \\
\text { the research you study } \\
\text { photography? }\end{array}$ & $(9)$ & $(2)$ & $100 \%$ \\
\hline
\end{tabular}

Interview of lecturers on photography and sourcing of illustration

Lecturers were asked if they insisted on students using photographic methods to source for their illustrations? Only 3 respondents representing $27 \%$ said yes; while 8 representing $\mathbf{7 3 \%}$ said no; they do not insist on any source and they were also asked if they advise their students on what or how to source for their illustrations? 9 of them representing about $\mathbf{8 2 \%}$ said no choice was given to them; while 2 of them representing about $\mathbf{1 8 \%}$ said yes they gave them choices. (Table three)

\section{Discussion of Results}

The results of interview obtained from students showed a $73 \%$ influence of the internet, when they were asked their first place choice for source of illustration while that of personal photographs had 27\% (see table one). This result from the interview with students went in line with the interviews with lectures. When the lecturers were asked if they did provide choices or insist on any choice for source of illustration, $82 \%$ said they did not provide any options, that the students were given the free option to source their illustrations from anywhere. Only $18 \%$ said yes, they insisted on choices more times outside the internet, but not with the aim of being original (see table three). $63 \%$ of students agreed that their lecturers had never insisted on where or how they got their illustrations which has agreed with $82 \%$ of lecturers who did not lead the students into any option. When the students were asked if they knew the purpose of the aperture in a camera, 63\% said they did not know while $37 \%$ said they knew. The results also indicated that $73 \%$ of lecturers did not insist on photographic methods, while $27 \%$ said they insisted. (see table two) 
Journal of Education and Practice

ISSN 2520-467X (Online)

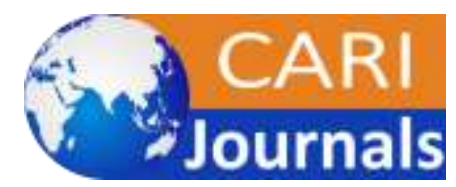

Vol.5, Issue No.4, pp 23 - 30, 2021

www.carijournals.org

\section{Conclusions}

A view of the interview results with students signifies that $87 \%$ said they did not know what the aperture in a camera was. This showed great lack of understanding of what is meant to be their instruments of trade, the camera: Which stands strong at the root of being original as a graphic artist. The aperture is that part of the camera that controls the entry of light. Among the steps suggested by Hodge (2011) was the need for one who wants to be original to experiment and capture random experiences. Capturing experiences faster for the graphic artist is through the eyes of a camera, though sketches might be a little slower, because it is more pains taking. The $73 \%$ interest on the internet as first choice had made the students abandon the idea of the use of the camera. It behooves the graphic artist to know his camera well. What has discouraged them more was the fact that their lecturers never insisted on how or where they got their illustrations, where $63 \%$ admitted that they got no direction from their lecturers. This agreed with $82 \%$ of lecturers who said in their interview that they had never specified source for them (see table three). When the students were asked the reasons they learn photography, 63\% said they did not know (see table two). This in its self, revealed a down turn on what they were meant to know.

$87 \%$ not knowing what the aperture was in a camera indicates a lowering of students creative ability. It is expected that while in the process of study creative photography must be mastered, such that it becomes a corner stone for originality in graphics. Lecturers must specify and insist on how students could generate illustrations using photography, this would help them to understand their camera more and constantly aim for originality. They should be made to know that short-cut syndrome would not bring about deep learning and understanding.

\section{Recommendations}

1. Lecturers must insist on students using cameras that have full functions that would bring full understanding of studio cameras.

2. Lecturers must insist that students avoid the use of phone cameras for their creative assignments or projects because; this is another temptation, no matter how good the resolution might be.

3. University authorities must as matter urgency provide enough functional cameras for the purpose of studies for students. This is important because students may not be able to afford them. Studio cameras with full functions are expensive.

\section{References}

Collins, N. (2015). Art glossary; encyclopedia of art; Illustrations: the art of illustrations in books, magazines \& newspapers. Retrieved from http://www.visualarts-cork.com/illustration.htm\#characteristics

Cullata, R. (2021). Operant conditioning .B. F. Skinner, www.instructionaldesign.org. https://www.instructionaldesign.org/theories/operant-conditioning/

Hill. S. (2013). A complete history of the camera phone/digital trends. Retrieved from: https//www.digitaltrends.com/mobile/camera-phone-history/ 
Journal of Education and Practice

ISSN 2520-467X (Online)

Vol.5, Issue No.4, pp $23-30,2021$

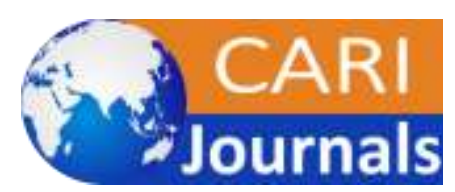

www.carijournals.org

Hodge, S. (2011). Design \& illustration. Design theory; teach yourself graphic design. A selfstudy course outline. Retrieved from:

https://design.tutsplus.com/articles/teachyourself-graphci-design-a-self-study-courseoutline,

https://so02.tci-thaijo.org/index.php/EDKKUJ/article/view/50190/41579

Josh .C (2019). Photography for beginners: A complete guide. Retrieved from https://expertphotography.com/a-beginners-guide-to-photography/

Long-Crowell E. \& Levitas J. (2021). Social exchange theory in relationships: definition, examples and prediction. www.study.com https://study.com/academy/lesson/interdependence-theory-definition-examplespredictions.html

Umegbewe, G.K, Ateh-Abang and Agbor. A.B (2010) Reinforcement and its educational implications. International journal of education, vol. 33, No.3 September, 2010 pp. 27-36.

Valerio. R. (2018). Is drawing a talent or a skill - Quora. Retrieved from: https://www.quora.com/is-drawing-a-talent-or-a-skill

www.tci-thaijo.org

Zhihui, F. (1996), Illustrations, text and the child reader. What are pictures in children's storybooks for? Reading horizons, vol.37, issue 2, Article 3. Retrieved from https://scholarworks.wmich.edu/cgi/viewcontent.cgi?article=1280\&context=reading$\underline{\text { horizons }}$ 